\title{
Thermal Factors of Die Casting and Their Impact on the Service Life of Moulds and the Quality of Castings
}

\author{
Darina Matisková $^{(1)}$, Štefan Gašpar ${ }^{(2)}$, Ladislav Mura ${ }^{(3)}$ \\ ${ }^{(1),(2)}$ Faculty of Manufacturing Technologies of Technical University in Košice \\ with seat in Prešov, Department of Manufacturing Management and Department \\ of Designing Technological Devices, Bayerova1, 08006 Prešov, Slovakia \\ e-mail: darina.matiskova@tuke.sk
}

(3) J. Selye University in Komárno, Faculty of Economics, Bratislavská cesta 3322, 94501 Komárno, Slovakia, e-mail: mural@selyeuni.sk

\begin{abstract}
This article deals with the analysis of the temperature factors of die casting and the conditions of the service life of moulds. It also describes a mechanism of the origin of internal structures and development of crystallisation grains of aluminium castings depending on the degree of undercooling. The monitored factors are very important in terms of production efficiency and the quality of the casting, which is positively reflected in the most important economic indicators of the production. In die casting, the melted metal is pressed under high temperature into a mould cavity of significantly lower temperature. The mould is then exposed to thermal strain of individual surface layers of the mould material. The speed of cooling of the castings in the metal mould increases, causing an increase of thermal gradients in the casting. Intensive heat exchange between the casting and the metal mould has a negative effect on fluidity, which increases the danger of incomplete replenishment and the occurrence of cold joints.
\end{abstract}

Keywords: thermal factors of die casting; service life of a mould; quality of a casting

\section{Introduction}

Die casting is a process for producing castings by die casting machines, where molten metal is injected into a permanent mould at high speed $\left(10-100 \mathrm{~m} \cdot \mathrm{s}^{-1}\right)$ and under high pressure, Fig. 1. It is a highly productive method of die casting with low dimensions tolerance and high surface quality. The quality of the castings filled under pressure is influenced by many technological factors, the basics of which are: speed of pressing during the cycle of casting, after pressure, the temperature of cast alloy, the temperature of the filling chamber, and the temperature of a mould. 


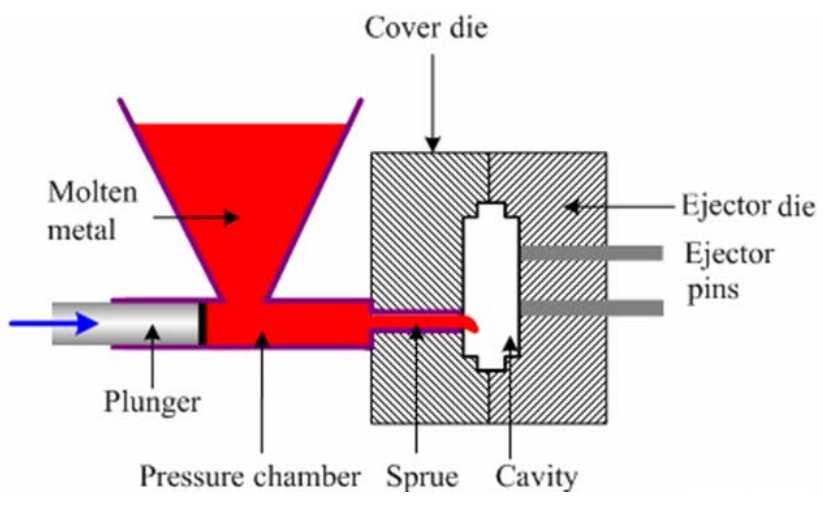

Figure 1

Scheme of die casting process

In die casting, the aforementioned input cost is divided among a large number of the products in a batch. It allows applying the solutions that secure the dimensions and shapes of the castings that are similar to the final parts with the highest possible quality of surface. Small or even no allowances for machining decrease material cost, number of operations, and overall work expenditure. This results in low weight, decreased price of the parts, high efficiency, and high competitiveness of the technology. $[1,3]$

Despite recent scientific research engaged in the issue of die casting, many factors and problems related to this technology remain unexplained. It also refers to the study of impact of thermal factors of casting on the service life of the moulds and the quality of the castings.

\section{Thermal Factors of Die Casting}

The basic thermal factors in the die casting process are: the temperature of cast alloy, the temperature of pressurised casting chamber, and the temperature of mould.

A significant precondition for the production of high quality castings is keeping an optimum temperature of the respective parts of the mould cavity surface. This temperature depends on the temperature of the material, the quantity of the metal, the method of the cooling of the casting mould, the thermal conductivity of the mould material, and the time during which the casting remains in the mould. Casting of too hot a material into a cold mould without sufficient surface isolation by a suitable lubricating medium causes great straining of the surface layers of the casting mould material. Casting of an alloy into a mould with insufficient surface temperature results in an early fall in the alloy temperature. The castings then have 
cold joints (Figure 1), breaks appear on the surface of castings (Figure 2), and even good looking castings are not of necessary quality, as in the material structure large internal strains occur due to great undercooling. In some cases it is demonstrated by fine surface cracks (Figure 3 ). In casting the alloy into a mould with high temperature of the mould cavity surface, diffusion of the alloy into the overheated mould surface occurs. After solidification, it is demonstrated by intensive adherence of alloy to a mould and increased bubbles and porosity.

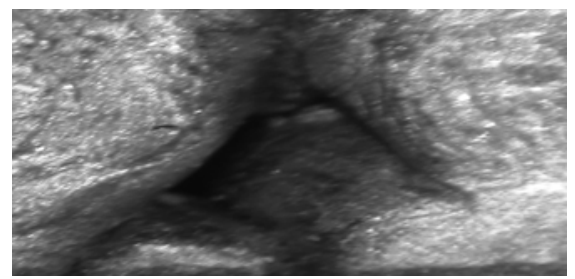

Figure 2

Cold joint

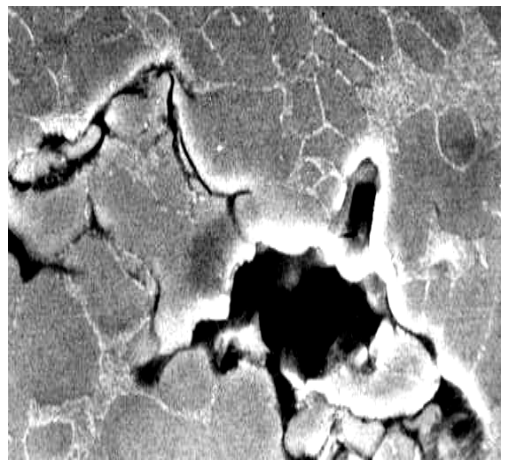

Figure 3

Internal scar

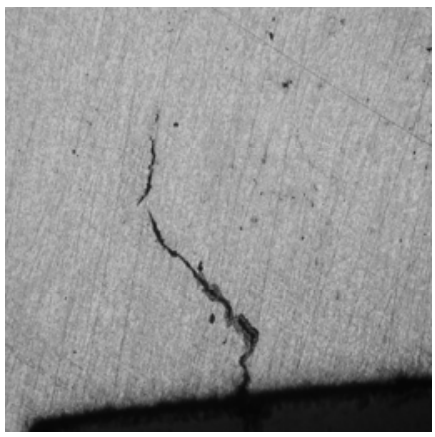

Figure 4

Surface cracks 
Temperature of a cast alloy - The casting of a very warm alloy into a cold mould cavity causes serious strain on the surface layers of the mould material. The temperature of the alloy for die casting has to be higher by about $10-20{ }^{\circ} \mathrm{C}$ than the initial crystallization temperature.

Temperature of a mould - the casting quality is significantly affected by the temperature regime of the mould. When the mould is cold, joints are formed in the casting and the surface quality of casting is insufficient. When the mould is very hot, the alloys are bonded to the mould and the amount of bubbles and pores grows. The temperature of the mould will be maintained constantly at approximately $1 / 3$ of the temperature of the cast metal. This is achieved by thermoregulation of the mould.

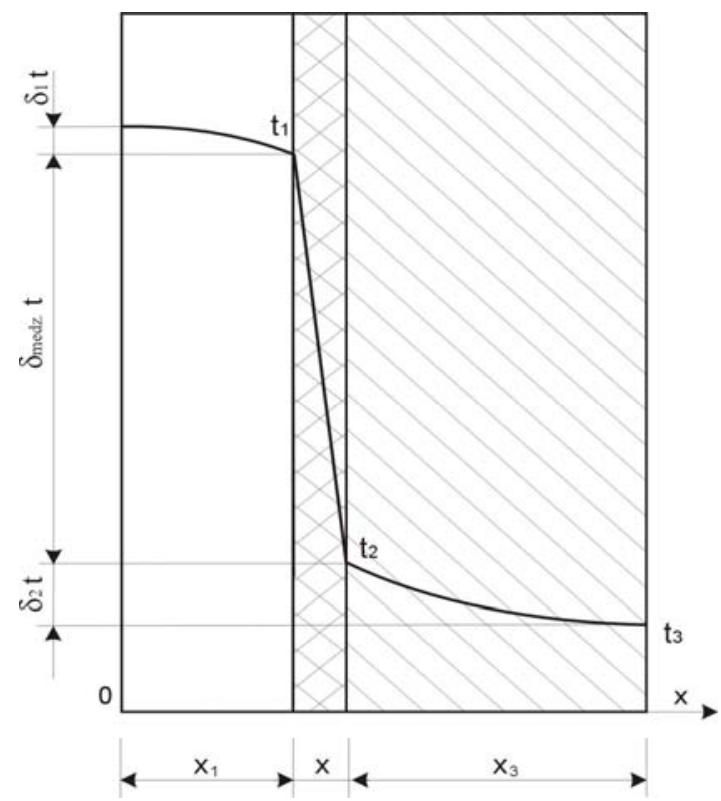

Figure 5

Temperature field of casting and mould

Temperature of a filling chamber - when the chamber is preheated before the casting process, the temperature of the cast alloy does not decrease before filling of the mould cavity.

The increased rate of cooling of castings in a metal mould in comparison with a sand mould causes an increase in temperature gradients in the casting. As a result, cure speed increases. Also the wide thickness of the gap between the casting and the metal mould, formed by a layer of the protective coating, causes temperature distribution, which is shown schematically in Figure 5. Basic thermal resistance is represented by the gap in which there is also the biggest temperature (gradient). 
One of the key issues of the metal moulds heat regime is keeping the balance of one thermal cycle.

The following applies for the thermal balance per one cycle:

$$
Q_{1}+Q_{2}-Q_{3}-Q_{4}=Q_{1}
$$

Where:

$Q_{1}$ - is the amount of heat required for preheating of the moulds [J],

$Q_{2}$ - is the amount of heat injected by casting [J],

$Q_{3}$ - is the amount of thermal energy transferred from the casting to the mould [J],

$Q_{4}$ - is the amount of heat minus the heat of the mould leaving the casting [J],

or:

$$
Q_{2}-Q_{3}-Q_{4}=0
$$

Then the amount of heat injected by the casting:

$$
Q_{2}=m_{k}\left[c_{L}\left(T_{1}-T_{s}\right)+l+c_{S}\left(T_{s}-20\right)\right],
$$

where:

$$
\begin{aligned}
& m_{k} \text { - is weight of casting }+0.6 \text { of intake weight }[\mathrm{kg}] \text {, } \\
& c_{L} \quad-\text { is the specific heat of molten iron }\left[\mathrm{J} \cdot \mathrm{kg}^{-1} \cdot \mathrm{K}^{-1}\right] \text {, } \\
& T_{1} \quad \text { - is the temperature of the liquid metal }\left[{ }^{\circ} \mathrm{C}\right] \text {, } \\
& T_{s} \quad \text { - is the solidus temperature }\left[{ }^{\circ} \mathrm{C}\right], \\
& l \quad \text { - is the latent heat of metal }\left[\mathrm{J}_{\mathrm{kg}}{ }^{-1}\right] \text {, } \\
& c_{S} \quad-\text { is the specific heat of solid metal }\left[\mathrm{J} \mathrm{kg}^{-1} \cdot \mathrm{K}^{-1}\right] \text {. }
\end{aligned}
$$

The amount of heat transmitted by the casting to the mould:

$$
Q_{3}=\alpha \cdot F_{o d l} .\left(T_{1}-T_{f}\right) \tau_{1},
$$

where:

$$
\begin{aligned}
& \alpha \quad-\text { is the heat transfer coefficient }\left[\mathrm{W} \cdot \mathrm{m}^{-2} \cdot \mathrm{K}^{-1}\right], \\
& F_{\text {odl }}-\text { is the casting surface }\left[\mathrm{m}^{2}\right], \\
& T_{f}-\text { is the temperature of the mould }\left[{ }^{\circ} \mathrm{C}\right], \\
& \tau_{l} \quad-\text { is the cooling time }[\mathrm{s}] .
\end{aligned}
$$

The amount of heat leaving the mould with the casting:

$$
Q_{4}=m_{k} \cdot c_{s}\left(T_{2}-20\right) \text {, }
$$


where:

$$
T_{2} \text { - is the temperature of the casting taken out from the mould }\left[{ }^{\circ} \mathrm{C}\right] .
$$

The heat balance equation is as follows:

$$
m_{k}\left[c_{L}\left(T_{1}-T_{s}\right)+l+c_{S}\left(T_{s}-20\right)\right]-m_{k} \cdot c_{s}\left(T_{2}-20\right)=\alpha \cdot F_{\text {odl } .}\left(T_{1}-T_{f}\right) \tau_{1}
$$

\section{Thermal Stress and Service Life of Moulds}

As per Figure 6, heat from the liquid metal passes into a mould surface and further through a mould wall.

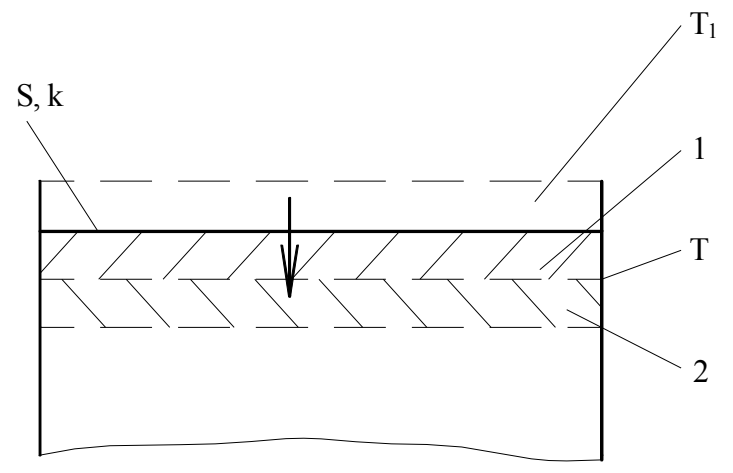

Figure 6

The surface layer 1 and the undersurface layer 2 at filling with the liquid metal

Then the heat differential $d Q$ from the metal passes into the mould during the time differential $d t$ :

$$
d Q=\alpha S\left(T_{1}-T\right) d t=m c d t
$$

where:

$\alpha$ - is the coefficient of heat transfer between the metal and the mould surface, $\left[\mathrm{W} \cdot \mathrm{m}^{-2} \mathrm{~K}^{-1}\right]$,

$S$ - is the contact area of the liquid metal and the mould $\left[\mathrm{m}^{2}\right]$,

$T_{1}$ - is the temperature of the liquid metal $\left[{ }^{\circ} \mathrm{C}\right]$,

$T$ - is the temperature of the mould $\left[{ }^{\circ} \mathrm{C}\right]$,

$m$ - is the mass of the mould surface layer [kg],

c - is the specific heat capacity of the mould material, $\left[\mathrm{J}^{\mathrm{kg}} \mathrm{kg}^{-1} \mathrm{~K}^{-1}\right.$. 
By arrangement and integration of the equation (8) we will get

$$
\int_{0}^{t} \frac{k S}{m c} d t=-\int_{T_{1}}^{T} \frac{d\left(T_{1}-T\right)}{T_{1}-T}
$$

After the integration:

$$
T=T_{1}\left(1-e^{-\frac{k S}{m c} t}\right)^{\left[{ }^{\circ} \mathrm{C}\right]}
$$

We can write for the heat transfer from the surface layer of the temperature $T_{1}$ into the mould body of the temperature $T$ during the time interval $d t$ :

$$
-m c d T=k S\left(T-T_{1}\right) d t
$$

After arrangement and integration:

$$
-\int_{T_{1}}^{T} \frac{d\left(T-T_{1}\right)}{T-T_{1}}=\int_{o}^{t} \frac{k S}{m c} d t
$$

After further arrangement:

$$
T=T_{1} e^{-\frac{k S}{m c} t},\left[{ }^{\circ} \mathrm{C}\right]
$$

The derived courses correspond to the measured results [1,3] in Figure 7.

$\mathrm{t}-$ it is time $[\mathrm{s}]$

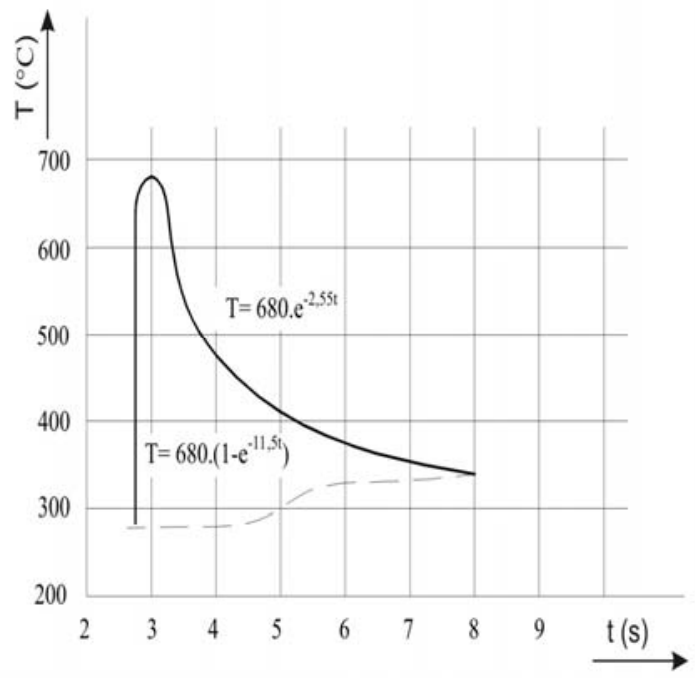

Figure 7

Course of the temperature in the experimental mould in die casting of aluminum alloy 


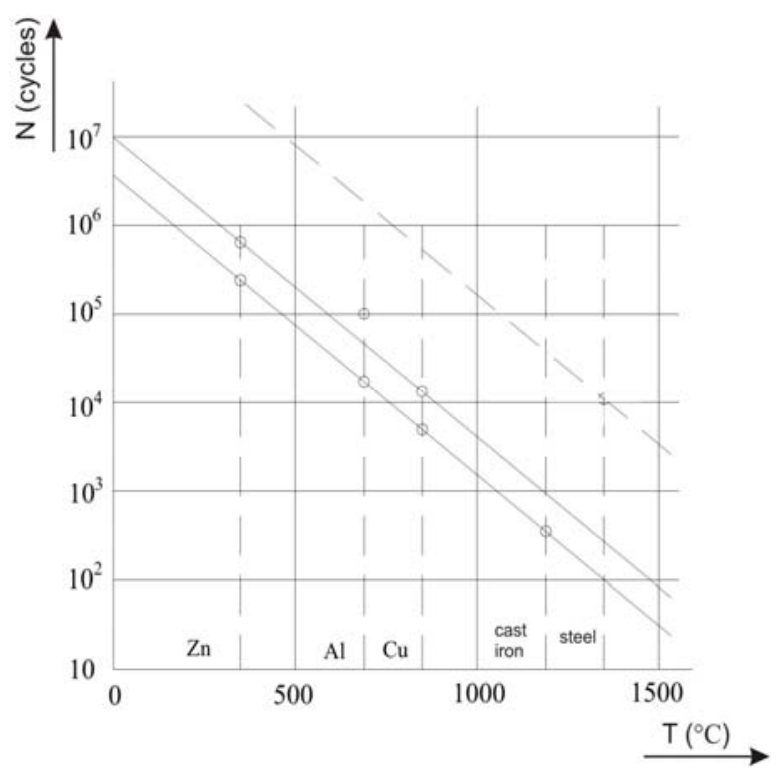

Figure 8

Dependence of the mould service life in die casting on casting temperature

To make it simple, we consider the surface layer of the mould as a total. In case the layer is loose after the liquid metal enters the mould, then dilatation occurs.

$$
\delta=\alpha\left(T_{1}-T_{0}\right)
$$

where:

$\delta$ - is dilatation of the mould [m],

$\alpha$ - is the linear coefficient of heat transfer $\left[\mathrm{W} \cdot \mathrm{m}^{-2} \mathrm{~K}^{-1}\right]$,

$T_{1}$ - is the temperature of the mould after the liquid metal enters the mould $\left[{ }^{\circ} \mathrm{C}\right.$ ],

$T_{0}$ - is the temperature of the mould before the liquid metal enters the mould $\left[{ }^{\circ} \mathrm{C}\right]$.

Because the surface layer is a part of the mould, it cannot dilate, and compressive stress arises in it:

$$
\sigma=\frac{\delta \kappa E}{\kappa-1}
$$

where:

$\sigma$ - is the compressive stress of the layer [Pa],

$\kappa$ - is the Poisson constant,

$E$ - is the modulus of mould elasticity [Pa]. 
This compressive stress causes tensile in the layer under the surface layer. However, after removing the casting at cooling of a previously under pressure deformed surface layer the tensile stress arises in it. By repeating this process as the thermal fatigue in the tensile stress there is a danger of crack formation. After hundreds of thousands or more, cycles it really happens, and thus the mould service life ends (Figure 8).

We consider the number $N$ of pressings of the liquid metal into the mould as a quasilinear function with an indirectly proportional dependence on the casting temperature $T$. Each elementary increase of the casting temperature $d T$ means a lowering of the indirectly proportional cycles of the mould service life

$-\frac{d N}{N}$

Then it applies that

$$
d T=-k \frac{d N}{N}
$$

where:

$k$ - constant,

After the integration from $T_{l}$ to $T$ and from $N_{l}$ to $N$ we will get:

$$
T-T_{1}=-k \ln N+k \ln N_{1}
$$

After arrangement and change to a decadic logarithm:

$$
\log N=A-K T
$$

where:

$\mathrm{A}$ and $\mathrm{K}$ are the constants

$$
K=\frac{2,3}{k}
$$

The relation (18) corresponds to actually measured results according to Figure 8, where the logarithm of cycles is $\mathrm{N}$ in the temperature of the die casting in the casting of single alloys. [14, 17] 


\section{Structural Analysis of Aluminium Castings}

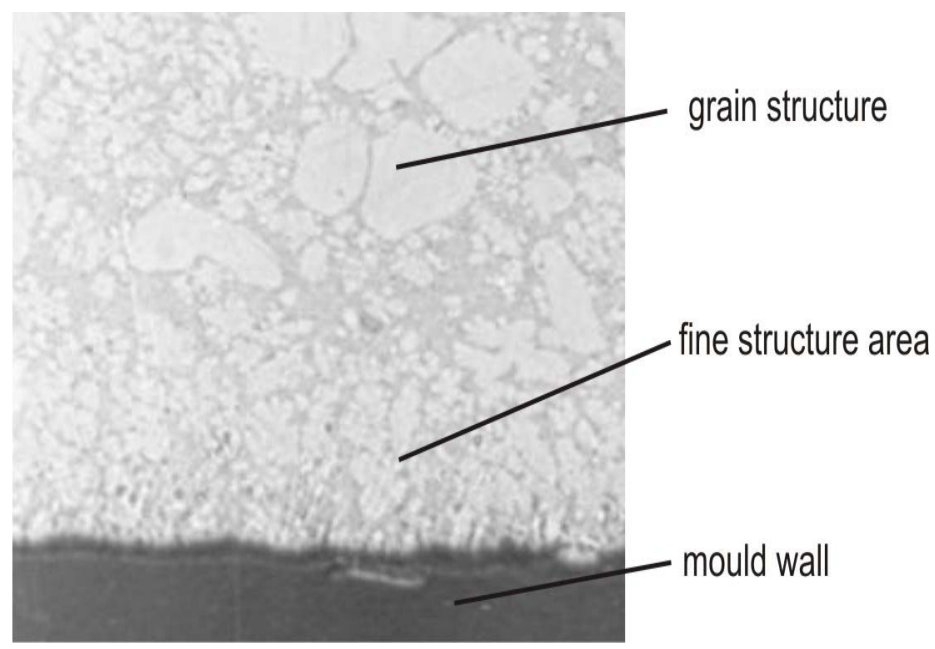

Figure 9

Microstructure of sample edge $/ 250 \mathrm{x} /$

For all analysed Al castings, the presence of extra fine crystals is typical, located in the area of the casting solidified at the face of a mould. The thickness of this area ranges from several $\mu \mathrm{m}$ to $1 \mathrm{~mm}$. In the scratch pattern (Figure 9) the smooth transition from the fine crystals to the area with thicker structure can be observed. The formation of the area with fine structure relates to the degree of undercooling at the face of the mould, which depends mostly on the temperature of the mould. By contact between the melt flow and the cool wall of the mould, the temperature of which is lower than the one of the melt, crystallisation arises at a very high degree of undercooling and precisely limited direction of heat removal. Therefore, the area of fine crystals develops with primary orientation in the direction opposite to the heat removal direction. $[8,9]$

The structure of aluminium castings of the analysed samples consists of $\alpha$ - solid solution (primary released) and eutectic (Figure 10). The eutectic appears to be a two-phase structure consisting of $\alpha$ - solid solution and silicon. Dark areas represent $\alpha$-solid solution and the white ones represent the particles of eutectic silicon. Even with 2000-fold enlargement, the readability of structure aimed at the determination of silicon morphology is indistinctive. Therefore, the analysis of eutectic silicon morphology was made by means of a reflection electron microscope (REM), (Figure 11) with 6000-fold enlargement. With greater enlargement of the area, the presence of eutectic adhesion of individual eutectic cells can be seen, demonstrated in the picture by bright zigzag strips of various length. The eutectic is anomalous, i.e. the eutectic elements cannot grow by the same speed due to whatever causes $[4,5]$. 


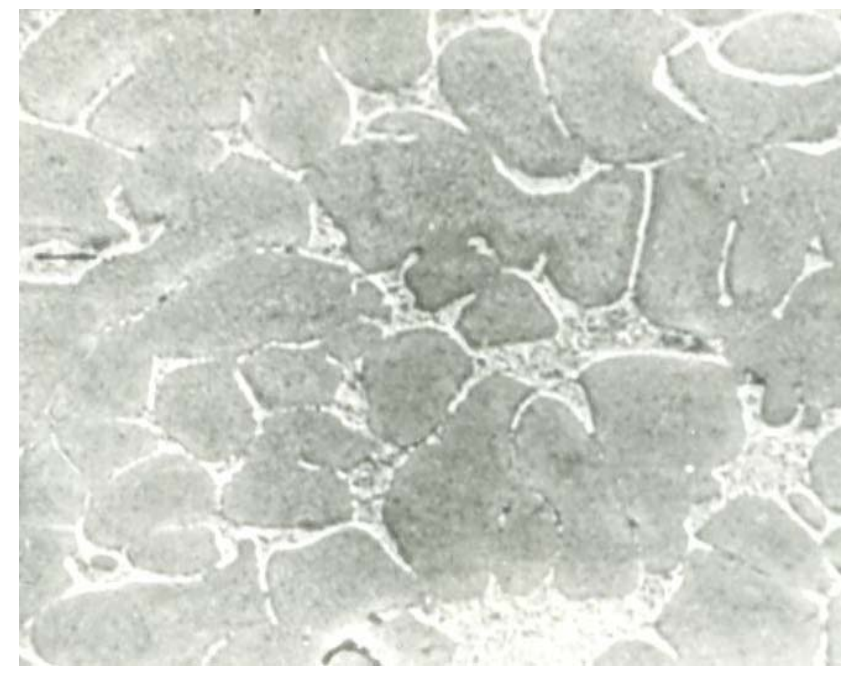

Figure 10

Basic structure $(2000 \mathrm{x})$

A fast growing phase is usually the phase with smaller volume rate. In the Al-Si system there are Si pseudo dendrites. The degree of undercooling necessary for the proceeding of the crystallisation queue for structural phases varies; therefore the width of present eutectic elements development area (i.e. area with a typical eutectic structure) depends on the gradient of the temperature of the border line between solid - liquid phase. Factors influencing the quality of a casting represented by mechanical characteristics of the casting are characteristics of $\alpha-$ phase and amount, size, and distribution of eutectic silicon. [6, 7]

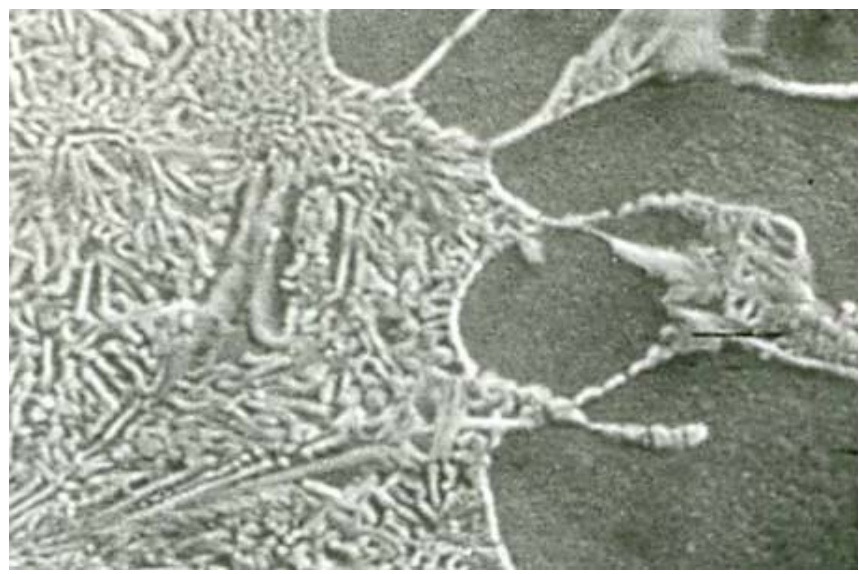

Figure 11

Adhesion of eutectic cells (6000x) 


\section{Conclusions}

The presented work is aimed at the evaluation of the impact of thermal factors of die casting on the service life of the casting mould and the quality of pressurised Al-casting represented by the structural parameters of the castings, which the individual mechanical characteristics directly depend on $[4,5]$.

In die casting, after certain cycles, thermal fatigue strain of the mould arises. It leads to the formation of cracks and ends the service life of the mould according to the equation (7) that expresses the dependence of the number of mould service life cycles on the casting temperature in the casting of single alloys.

Further to the analysed scratch patterns of all samples it can be stated, provided that castings are produced from alloy of the same chemical structure, that the structural parameters are influenced mostly by the speed of cooling. The speed of cooling is primary controlled by the die casting temperature and the thermal content of the cast alloy (casting temperature). If the mould temperature is the same, the structural parameters are influenced only by temperature of the casting process $[1,3]$.

The structure and characteristics of the cast metals and alloys are therefore significantly influenced by the conditions of crystallisation. With technological interventions in the crystallisation process, the mechanical characteristics and structure may be improved. The crystallisation motion in practice is mostly influenced by the change in the speed of cooling. The increase of undercooling causes significant solidification of the melt under pressure due to the intensive heat exchange between the melt and the mould, which stimulates the development of areas with fine-grained crystals in the casting at the face of the mould, which smoothly moves to the area with thicker structure into the centre of the casting.

\section{Acknowledgement}

This article has been prepared within the project VEGA No. 1/0593/12: Research of Technological Parameters Influence of Die Castings and Design Modification of the Die System of the Casting Machine on Mechanical Properties of Die Castings of Lower Mass Category Made of Silumin.

\section{References}

[1] Belopuchov, A. K. a kol.: Casting of Metals under Pressure, Manufacturing of Engineering, Moskva, 1975

[2] Laudar, L.: Casting of Metals Under Pressure, SVTL Bratislava, 1964

[3] Malík, P., Gašpar, J., Paško, J.: Impact of Technological Factors of Pressure die Casting on Mechanical Properties of Castings) - 2009. In: Manufacturing Engineering. Roč. 8, č. 4 (2009), s. 32-37. - ISSN 13357972 
[4] Ragan, E.: The Process of Casting Metals under Pressure, Technical University in Košice, FVT with seat in Prešov, Prešov 1997

[5] Valecký, J. a kol.: Casting of Metals under Pressure, STNL Praha, 1963

[6] Vinarcík, E. J.: High Integrity Die Casting Processes, John Wiley and sons, New York, 2003

[7] Gašpár, Š. - Maščeník, J. - Paško, J.: The Effect of Degassing Pressure Casting Molds on the Quality of Pressure Casting. In: Advanced Materials Research. Vol. 428 (2012), p. 43-46. - ISSN 1022-6680

[8] Bigoš, P. - Puškár, M.: Engine Output Increase of Two-Stroke Combustion with Exhaust System Optimization, In: Strojarstvo. Vol. 50, No. 2 (2008), pp. 69-76, ISSN 0562-1887

[9] Eperješi, Š. - Malík, J. - Vasková, I. - Eperješi, L. - Fecko, D.: Comparison of Achieved Parameters Results of High-Strength Ductil Cast Iron by Different Way of Heat Treatment. In: Archives of Foundry Engineering. Vol. 11, special no. 1 (2011), pp. 55-57, ISSN 1897-3310

[10] Vajsová, V.: Optimization of Homogenizing Annealing for Al-Zn5.5Mg2.5-Cu1.5 alloy. In. Metallurgist. Vol. 54, No. 9-10 (January 2011), pp. 618-622, ISSN 0026-0894

[11] Belov, N. A. - Belov, V. D. - Alabin, A. N. - Mishurov, S. S.: New Generation of Economically Alloyed Aluminum Alloys. In: Metallurgist. Vol. 54, No. 7-8 (November 2010), pp. 409-414, ISSN 0026-0894

[12] Zuberová, Z. - Sabirov, I. - Estrin, Y.: The Effect of Deformation Processing on Tensile Ductility of Magnesium Alloy AZ 31. In: Metallic Materials. Vol. 49, No. 1 (2011), pp. 29-36, ISSN 0023-432X

[13] Yin, D. L. - Weng, L. K. - Liu, J. Q. - Wang, J. T.: Investigation of Microstructure and Strength of AZ80 Magnesium Alloy by ECAP and Aging Treatment. In: Metallic Materials. Vol. 49, No. 1 (2011), pp. 37-42, ISSN 0023-432X

[14] Matisková, D.: Economic Reasons for Automatic of Component Production / - 2011. In: Manufacturing Engineering. N. 3 (2011), s. 56-58, ISSN 13357972

[15] Rózsa, Z.: Enterprise - a System with a Target Behavior In: Sedlák, M.: Business of Economy Bratislava: Iura Edition 2010, ISBN 978-808-8078$317-4$

[16] Šebej, P., Hrubina, K., Wessely, E.: Creation of Production Planning Using the Mathematical Model and Multi-Criterion Optimal, In: Annals of DAAAM for 2004, Vienna: DAAAM International, pp. 413-414, ISBN 3901509429 
[17] Modrák, V.: Functionalities and Integration Possibilities of Manufacturing Execution Systems, 2009. In: Annals of Faculty of Engineering Hunedoara - Journal of Engineering. Vol. 7, No. 1 (2009), pp. 51-56, ISSN 1584-2665, http://annals.fih.upt.ro/ANNALS-2009-1.html 